\title{
Prologue: the vanishing adulteress
}

De principis instructione, a moral treatise on the cultivation of virtue, composed by the Angevin courtier, scholar and litterateur, Gerald of Wales (c.1146-c.1223), exists today in only a single copy, a mid-fourteenthcentury manuscript of unknown provenance. ${ }^{1}$ There are no indications that the text was widely circulated, much less that it ever reached the eyes of rulers. Written and revised at intervals between 1190 and 1217 , De principis instructione consists of three books (distinctiones), intended to teach both princes and prelates. ${ }^{2}$ The first distinctio looks very much like a traditional speculum principis, praising virtues such as modesty (modestia), chastity (pudicitia) and prudence (prudentia), and explaining the difference between a king and a tyrant. The two subsequent books provide a narrative of how those virtues had, or had not, been practised by princes, in the form of a contemporary history of the Angevin and Capetian dynasties. As Gerald himself explained, the first book instructs through the precepts of theology and ethics, the second and third teach rulership through exempla. ${ }^{3}$

Along with much of Gerald's voluminous and varied oeuvre, De principis instructione was edited and printed in the late nineteenth century as part of the Rolls Series, one of seven substantial volumes. ${ }^{4}$ The Victorian editors, however, found very little worthy of remark in the first book of De principis instructione, and, when preparing the text for publication, they excised many of the quotations and exempla which Gerald had so carefully worked into a coherent whole. Most recent scholars have agreed with that nineteenth-century judgment, regarding the first book of De principis instructione as little more than a collection of trite commonplaces culled from florilegia collections, which reveals little about the political, intellectual, or cultural life of late twelfth- or early thirteenth-century England. Robert Bartlett, Gerald's modern biographer, who has led the way in 
recognising the distinctiveness of Gerald's other works, did not find the first book of De principis instructione particularly engaging. He characterised the book as 'neither original nor very illuminating', a compilation of quotations intended to reinforce 'moral platitudes', and quite separate from the more valuable historical information contained in the second and third distinctiones. There the meat of Gerald's text is to be found, in a critical history of twelfth-century rulership, its personnel and its failings. Thus, since serious academic study of the middle ages began, De principis instructione has been available in truncated - one is tempted to say 'mutilated' - form. Only when consulted in manuscript form could Gerald's careful selection of scriptural and classical quotations - and his own commentary upon them - be read and appreciated in full. ${ }^{6}$

Contained within Gerald's forlorn, forgotten and seemingly formulaic first distinctio is a chapter on clemency (de principis clementia). The focus of the discussion is the judicial role of the prince, and Gerald urges those who have the power to punish to control their anger, to remit offences and to mitigate due punishment.? To this end he quotes from a variety of authorities: from classical poets, moralists and historians (including Lucan, Ovid, Sallust and Cicero); from scripture (the prophets, the psalms, the gospels); from the exemplary history of the 'proto-martyr' Stephen, who prayed for his persecutors even while they stoned him to death; and from Ambrose of Milan's treatise on Christian duties, De officiis. Among these, Gerald takes an episode from the Gospel of John, the story of the woman caught in adultery (John viii.1-11), as an example of clemency. The guilty woman had been presented to Jesus by the Pharisees, who demanded that he pass sentence upon her. The law required that she be stoned to death, but Christ refused, arguing that only a sinless man could justly execute the woman. This pericope - like much other material dealing with moral theology - has been cut out of the Rolls Series edition of Gerald's text. That removal, in many ways, typifies the more widespread neglect of the practical influence and significance of moral theology by medieval historians. For Gerald to cite the example of Christ forgiving a sinful woman may have seemed to Victorian editors simply to represent a repetitious, formulaic argument for clemency. In fact, this passage has hugely important ramifications for the way in which twelfth- and early thirteenth-century authors sought to bring to bear the moral guidance of scripture on their interpretation of the law.

The episode of the woman caught in adultery was interpreted by medieval readers according to two distinct strategies. It had a central place in legal discussions about interpretation of law and dispensation from written law. In canon and civil law, John viii formed the basis for a legal stipulation 


\section{Prologue: the vanishing adulteress}

concerning the procedural requirement for witnesses. Canonists and civilians specified the legal implications of the gospel passage: Christ had refused to condemn the adulteress because no witness to her crime could be produced: without a witness or witnesses to attest to the proof of the charges, judgment was manifestly unsound. In that legal tradition, the pericope said nothing about morality, but a great deal about procedure. By contrast, the interpretation offered by Gerald in De principis instructione takes Christ's treatment of the adulteress as a plea for mercy in judicial sentencing. Gerald follows glosses, scriptural commentaries and sermons in which Christ's words ('let he who is without sin throw the first stone') were treated as an admonition to the judge. Those appointed to sentence must be ever mindful of divine judgment on their own sins, and their own desperate need for mercy from the divine judge, lest they act too hastily or too severely towards the earthly sinners brought before them. In De principis instructione, Gerald places the example of the adulteress next to the injunction 'love your enemies and pray for those who persecute you' (Matthew v.44), and the example of Christ's forgiveness for his persecutors at the moment of his crucifixion (Luke xxiii.34). ${ }^{8}$ Deployed in this context, then, Gerald clearly intended the woman caught in adultery to stand as a demonstration of how the judge should temper the harshness of punishment. Far from adding to a list of moral platitudes, Gerald was weighing in on a debate concerning how love for one's fellow man or woman might override the strict punishment pronounced by law.

The exemplum of the woman caught in adultery has obvious intellectual and cultural significance, and Gerald's choice here connects him to a long-running tradition of moral debate. The implications of the 'legal' interpretation of John viii - the doctrine of witnesses - has been discussed extensively, and the importance of this scriptural story in the development of ius commune legislation has been examined at length in modern historiography. Yet the interpretation of John viii according to moral theology - reading Christ's refusal to judge a sinner as an exhortation to clemency, the interpretation here provided by Gerald - has received almost no attention whatsoever from medieval historians. The argument of this book is that the role of moral theology in the understanding and application of law - exemplified here in the ramifications of the story of the adulteress repays careful historical attention. Readings of moral theology and theological traditions shaped medieval responses to law, and, more particularly, considerations of how law should be implemented. Medieval theologians used scripture to argue that the demands of moral justice, not the dictates of written law, should claim primacy in sentencing. Theologians engaged 
with practice and, just as importantly, lawyers took notice. Most significantly of all, passages such as John viii were deployed to suggest that sometimes true justice lay in the mitigation of punishment and in the exercise of mercy. The definition of justice was, in short, just as much a matter for the schools of theology as it was for the schools of law. Examining medieval readings of John viii, as well as other scriptural, patristic and classical exempla, illuminates what may conveniently be termed the 'moral tradition' of justice. This tradition should not be dismissed as platitudinous, trivial or trite - theologians wielded real influence in shaping the ways in which the relationship between judgment, justice and the law was understood by contemporaries, and their discussions informed contemporary legal practice. That, in essence, is the underlying rationale for this book: we grasp only half of what it was to be a medieval judge if we do not grapple with the moral theology of judgment. Simply put, the adulteress, in her dual symbolism - bestriding the domains of theology and law - must be restored to the argument.

\section{Notes}

1 Gerald of Wales, 'De principis instructione', BL, MS Cotton Julius B XIII, fos $48 \mathrm{r}-173 \mathrm{r}$.

2 Gerald of Wales, De principis instructione, in Opera omnia, ed. J. S. Brewer, J. F. Dimock and G. F. Warner, RS 21 (8 vols, London, 1861-91), 8, praefatio prima, 5-6. 3 Ibid., 6.

4 For the history of the series see David Knowles, Great Historical Enterprises; Problems in Monastic History (London, 1963), 99-134.

5 R. Bartlett, Gerald of Wales: A Voice of the Middle Ages (2nd edn, Stroud, 2006), 63. One significant exception to this modern neglect of the text is I. Bejczy, 'Gerald of Wales on the cardinal virtues: a reappraisal of De principis instructione', Medium Aevum 75:2 (2006), 191-201.

6 A situation which will be remedied with the expected publication of Robert Bartlett's edition of De principis in 2018.

7 De principis, 1.7, 21-7.

8 BL, 'De principis instructione', 1.7 , fo. $55^{\text {r. }}$ 